sciendo Порівняльна професійна педагогіка 8(3)/2018

Comparative Professional Pedagogy 8(3)/2018

DOI: $10.2478 /$ rpp-2018-0044

Undergraduate Student, FARAZ YUSUF KHAN, Electronics \& Communication Engineering Department,

Faculty of Engineering, Integral University, India Address: Kursi Road, Lucknow, Uttar Pradesh, India E-mail: Ferez1905@outllook.com

Doctoral Student, SHRISH BAJPAI, Electronics \& Communication Engineering Department, Dr. A.P.J. Abdul Kalam Technical University, Address: Sector 11, Jankipuram Vistar, Lucknow, Uttar Pradesh, India E-mail: shrishbajpai@gmail.com

\title{
ELECTRICAL ENGINEERING EDUCATION IN INDIA: PAST, PRESENT \& FUTURE
}

\begin{abstract}
The present paper deals with the issue of Electrical Engineering, particularly its impact and standard of education in India from its initiation till present date. We have explored the transition of Electrical Engineering from disciplines of science to a discipline of engineering and technology. A comprehensive study of Electrical Engineering education framework in India at various stages has been done along with a comparison of educational institutes among BRICS nations, namely Brazil, Russia, India, China and South Africa. We have also acknowledged Electrical Engineering as an important domain of engineering and technology. Indian Government's efforts to improve the quality of Electrical Engineering education in India through internet based interactive online tools and its endeavors to decrease the rising levels of greenhouse emissions for the betterment of our environment has been appreciated in this paper. We have analyzed a plethora of Electrical Computer Aided Design (ECAD) simulation tools, available for the welfare of electrical engineering academia, as well as industry based electrical engineering applications. Electrical Engineers are destined to play a decisive role in the socio-economic future of India and the world, as they have been doing this since the $19^{\text {th }}$ century. Keeping this fact in mind, we have decided to refer to the present employment opportunities available in India covering the private sector as well as the public one. The role of renewable energy in the creation of numerous sustainable jobs for the already huge and exponentially growing youth population of India has a mention in this paper. In conclusion we have formulated some recommendations to educational institutes and Indian Government which will help Electrical Engineering academia-industry flourish in the near future.
\end{abstract} in India.

Keywords: Electrical Engineering, Technical Education System, Engineering Education

\section{INTRODUCTION}

Human civilization's foray into the world of electricity began as early as 600 B.C.E when Thales of Miletus, a Greek philosopher, discovered static electricity by rubbing fur on substances such as amber. Since then the harnessing and utilization of electricity has 
been the bedrock as well as the driving technology behind human civilization's quest to better itself. However, it wasn't until 1800 that the first breakthrough was provided by Alessandro Volta when he invented the electrical battery. Electricity soon began to influence the mannerisms of human life with Francis Ronalds' building the first working electric telegraph in 1816, Pavel Yablochkov inventing the electric carbon arc lamp in 1876 and Alexander Graham Bell inventing the telephone in the same year (Bell, 1876; Borisov; 2016; Thue, 2016). Early electrical inventions and discoveries were concerned with 'electrification' where fossil-fuel powered devices such as lamps and generators were replaced with more efficient electrical alternatives. This trend would continue into the late $19^{\text {th }}$ century and early $20^{\text {th }}$ century when electric railway locomotives started replacing conventional coal and fossil fuel powered railway locomotives. The American Institute of Electrical Engineers (AIEE) was founded in 1884, in New York City, USA. Its founders included Nikola Tesla, Thomas Alva Edison, Elihu Thomson, Edwin J. Houston, and Edward Weston. These personalities had already been involved in related fields such as physics, chemistry, and mechanics and decided to promote, explore and discover the new field of Electrical Sciences along with its industrial applications through AIEE. We witnessed two great minds competing against each other in the late 1880s and early 1890s with Thomas Edison's direct current on one side and George Westinghouse's alternating current on one side. George Westinghouse's alternating current won the battle as it proved to be an inexpensive and more efficient model for the utilization of electricity (Keithley, 1999; Seely, 1999).

The $20^{\text {th }}$ century witnessed mankind's first modern war, The First World War, and naval vessels could then use precise electrical signaling lamps in order to communicate with other ships instead of the vague flames and flares, Electric lamps also enabled these ships to communicate with the help of codes, thereby outwitting enemy ships. Pioneers of war strategy found defensive capabilities in electric searchlights which could be used to detect enemy aircraft during night time. Radio became an indispensable part of war for it could then be used to transmit voice rather than code which was made possible by electron tube, oscillator and amplifier. Even before the United States entered World War 1 its scientists had developed a two-way radio system for aircrafts which could exchange radio signals over a range of 160 miles. This technology proved invaluable in the development of air traffic control several years later. In the year 1918, Kurt Huldschinsky found the solution for the problem of rickets which plagued children of Berlin through mercuryquartz lamps which emitted ultraviolet light. Years later researchers found out that vitamin $\mathrm{D}$ was necessary to produce calcium in bones, the process which was initiated by ultraviolet light (Holmøy, \& Moen, 2010).

India stands second on the list of most populous nations, seventh on the list of the largest countries by total surface area and third on the list of the largest economies by Purchasing Power Parity (PPP). According to India's most recent census (2011), it has a populace of 1.2 billion and counting with $74 \%$ of its occupants being classified as literate (Khare et al., 2015). India has one of the largest populations of young generation in the world. Today India has 29 states with seven union territories. Introduction of electricity in India began with the establishment of Calcutta Electric Supply Corporation (CESC) on the $17^{\text {th }}$ of April 1899 (Sarkar, 2015). The first concrete step towards urban electrification in India was taken soon after the introduction of electricity when Harrison road in Calcutta became the first electrically illuminated street in India in 1891. As soon as the concept of electrical power was introduced in Calcutta it started replacing horse driven trams, gas- 
sciendo Порівняльна професійна педагогіка 8(3)/2018

Comparative Professional Pedagogy 8(3)/2018

illuminated street lighting and fossil fuel powered motors which were used for industrial purposes by 1920 (Sarkar, 2017). The idea of generating electricity via force of running water was first implemented in 1882 at Niagara Falls, USA, by 1887. This technology was implemented near Darjeeling through Sidrapong Hydroelectric Plant. Work commenced on a Hydroelectric Powerplant at Beadon Falls, Shillong, in 1921. In October 1923 Shillong witnessed electric illumination (Singh, 2015). India has taken rapid strides in the field of electrical technology in terms of research and development, as well as electrification since its independence. While 94 percent of Indians living in urban areas have electricity, only 67 percent in rural areas have access to electrical facilities. However, with the implementation of several nationwide rural electrification schemes such as the Deendayal Upadhyaya Gram Jyoti Yojana (DUGJY), which absorbed the erstwhile Rajiv Gandhi Grameen Vidyutikaran Yojana (RGGVY), the latter statistic is set to increase. The electrification of rural areas has been one of the top priorities of the Indian Government since independence, as investment in rural electrification results in numerous economic benefits, as well as social development since $68.84 \%$ of India's population resides in rural areas (Palit, \& Bandyopadhyay, 2017).

\section{THE AIM OF THE STUDY}

Our study is aimed to find the prevalent status specific to electrical engineering field and electrical engineering education in India, its impact on the present and future socio-economic landscape of our country. We have also outlined the steps taken by the Indian Government in promoting and exploring various aspects of Electrical Engineering such as renewable energy. The changing scenario of automotive industry from conventional fossil fuel-based engines to electric engines presents a golden opportunity for electrical engineers in India. Also, the booming sector of renewable energy in India is generating employment for undergraduate \& postgraduate students (Bajpai, \& Kidwai, 2017).

\section{THEORETICAL FRAMEWORK AND RESERCH METHODS}

The problem of electrical engineering education has been covered by many researchers (C. Canizares, A. Chakraborty, Z. Faur, V. Murti, M. Roy, M. P. Singh, F. Terman, W. Thue et al.). The principles of this research are to collect data related to electrical engineering education associated with its status in India from the technical institute in India. Similar type of work has been performed by the researchers in the field of control, production, manufacturing, industrial, renewable engineering. Data for subjects in courses related to RF and Microwave Engineering has been sourced from websites of regulating bodies concerned with Engineering and Technology, such as All India Council for Technical Education (AICTE) and University Grants Commission (UGC). Syllabus for courses concerned with Electrical Engineering has been analyzed from website of National Institute of Technology-Tiruchirappalli while syllabus for PG courses in Electrical Engineering has been scrutinized from webpages of various Institutes of National Importance. The obtained information has been processed with the help of such methods as deduction and induction, synthesis and analysis.

\section{RESULTS}

There exist a total of 4587 Polytechnic institutions in India which offer a Diploma in Engineering Degree across India as of the year 2017-18. This course involves 3 years/6 semesters and covers 25-30 theory subjects, 10-15 laboratory subjects and a final year project. Students must pass their $10^{\text {th }}$ board exam to be considered for a Diploma in Engineering Degree. Undergraduate degrees in engineering and technology are provided by a total of 4397 institutions in India as of the year 2017-18. Minimum criteria to be eligible for an undergraduate degree in engineering or technology is that students must pass their $10+2$ board exams and a national level Joint Entrance Exam (JEE) which is held in two stages - a main stage and an advanced one. Performance of a student in JEE along with 
their $10+2$ results are used as a measuring scale for admissions to the country's Institutes of National Importance, solely dedicated to engineering and technology. They include Indian Institute of Technology (IIT), National Institute of Technology (NIT), Indian Institute of Information Technology (IIIT) with some other technical premier universities \& institutions (AICTE Report, 2017). India has 29 states and most of these states conduct their own entrance examination for UG programs offered by institutions under their jurisdiction. Several private institutes conduct their own entrance exams in conjunction with JEE for admissions to undergraduate programs for engineering or technology. A national level Graduate Aptitude Test in Engineering (GATE) is conducted by any one of the IITs for admission to post-graduate engineering or technology programs. Upon passing the GATE cut-off, a candidate is also required to pass an interview held by the IIT to which he has applied for post-graduation. GATE score-card is the measuring scale for admissions in post-graduate technology or engineering programs offered by the country's Institutes of National Importance dedicated to engineering and technology. Admissions to doctoral programs are conducted through several exams held by the concerned institute's department based on the specialization chosen by the candidate after an interview. UG programs such as B.E/B. Tech include $25-35$ theory courses with $15-25$ laboratory courses along with the final year major project. PG programs such as M.E./M. Tech include 10 theory \& 2 laboratory courses with the final semester completely dedicated to the chosen specialization in their specific chosen field (Khare et al, 2014). Financial support is provided in the form of scholarships to meritorious students by institutions as well as the government. Candidates must work under the guidance of a supervisor for the completion of their doctoral degrees which are offered in full time as well as part time versions. Scholarships for students of doctoral degrees are offered by institutions and may demand passing various national level exams to avail grants for their research (Khare et al, 2016).

B.E./B. Tech courses present $10-15$ core courses which are directly involved with Electrical Engineering. The rest of the courses are related to electronics engineering, mechanical engineering, instrumentation engineering, and management and, in some cases, humanities (Bajpai et al., 2016). Lab affiliated courses involve student working on electronic devices, DC machines, transformers, power electronics and power systems. First year UG curriculum includes major subjects from science, engineering and humanities background. Basic Electrical is offered as a compulsory subject to all engineering branches during freshman year which covers the inceptive concepts related to electrical engineering. Second year subjects are related to engineering mathematics, electronic devices and basic electrical instrumentations. Third year core subjects are focused on power system, communication system, control system and microprocessor. A couple of electives have been offered by the department which is more focused on the area in which students want to work and design the project. Final year elective subjects include open electives and perpetual electives. Subject related to electronic devices, instrumentation and computer networking have been offered as compulsory subjects. Control Systems, a subject which is more focused on controlling of a system through feedback without any human interaction, is offered as a compulsory subject for Mechanical Engineering and Electronic Engineering UG students (Murti, 1972). In pre-final year, courses related to renewable energy, which include solar energy, wind energy and bio-mass energy, are offered as open elective subjects to other departments' UG students. Final year major project calls for the students working on both core and future aspects of Electrical Engineering such as induction motors, industrial power 
Sciendo Порівняльна професійна педагогіка 8(3)/2018

Comparative Professional Pedagogy 8(3)/2018

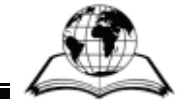

consumption, renewable energy systems and wireless power transfer. National Institute of Technology in Tiruchirappalli has indoctrinated a model syllabus for undergraduate programs in Electrical Engineering, inculcating core electrical engineering subjects, mechanical engineering and electronics engineering subjects (EE department, 2018).

Since Electrical Engineering is a mother-branch of engineering, PG courses, such as M.E./ M.Tech, are offered by most institutions across India. Figure 1 displays the variety of M.E./M. Tech offered by Indian Institutes of Technology in various specializations of Electrical Engineering. All Institutes of national importance concerned with engineering and technology offer or plan PG course in Electrical Engineering. Curriculum for PG in Electrical Engineering changes with respect to technological advancements and industry requirements of the time. Second year of PG in Electrical Engineering is devoted to dissertation and project activity in a chosen field. Candidates can apply for doctorate in Electrical Engineering in different subject matters, such as Electrical Energy and Power Systems, Power Conversion, Microelectronics and Nanostructures along with many more fields. Students enrolled in such doctoral programs perform theoretical or real-time practical analysis for their doctoral thesis. Industries investing a substantial amount in research through doctoral educational programs are BHEL, NTPC, Tata Power and many others. This amalgamation of industries and research scholars helps to escalate the growth of Indian economy and create an innovative atmosphere in the country.

Status of EE Education in Indian Institute of Technology

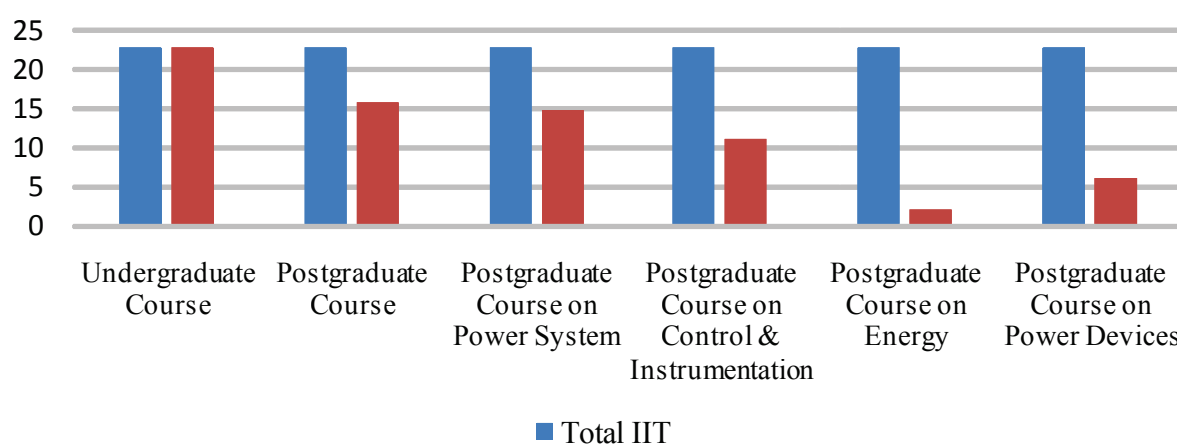

Fig. 1. Status of EE Education in Indian Institute of Technology

First year UG curriculum includes major subjects with science, engineering and humanities background. Basic Electrical is offered as a compulsory subject to all engineering branches during freshman year and covers the inceptive concepts related to Electrical Engineering. Second year subjects are related to engineering mathematics, electronic devices and basic electrical instrumentations. During the third year core subjects focused on power system, communication system, control system and microprocessor are covered. A couple of electives are offered by the department, which are more focused on the area in which students want to work and design the project (Terman, 1976). Final year elective subjects include open electives and perpetual electives. Subject related to electronic devices, instrumentation and computer networking are offered as compulsory subjects. 
Control Systems is a subject which is more focused on controlling the system through feedback without any human interaction. It is offered as a compulsory subject for Mechanical Engineering and Electronic Engineering UG students. During a pre-final year, courses related to renewable energy (solar energy, wind energy and bio-mass energy) are offered as open elective subjects to other departments' UG students (Chakraborty et al., 2018). Availability of UG courses for Electrical Engineering in National Institutes of Technologies is shown in Figure 2.

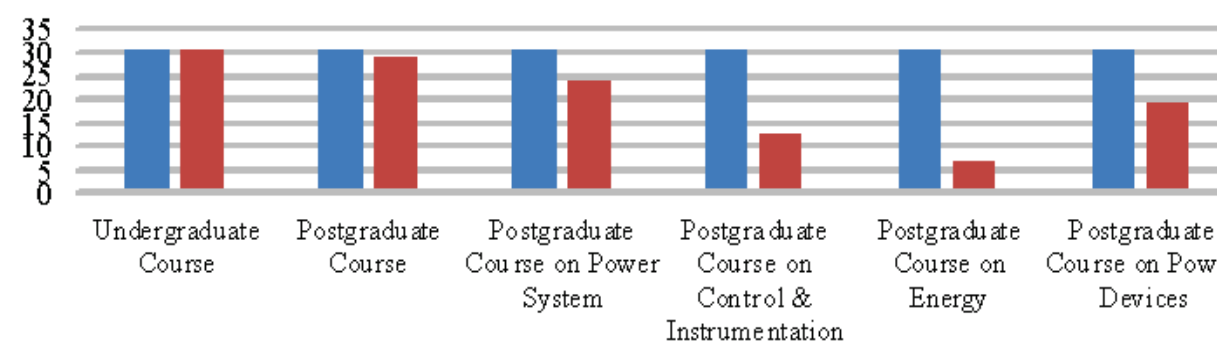

Total NIT

Fig. 2. Status of EE Education in National Institute of Technology

MATLAB and Mathematics are the go-to choice for Electrical Engineering academiaindustry for solving mathematical computation problems through simulation (Canizares et al., 1997). Scilab, GNU Octave, Maxima, SageMath are some open source tools useful for solving mathematical computation problems (Khare, 2016). Indian Government has taken a plethora of steps for the betterment of education infrastructure in the country. NPTEL is one of these significant steps. NPTEL is a brain child of IITs and IISc and is funded through Ministry of Human Resource Development (MHRD). By means of NPTEL these institutions have created an online free for all databases of engineering and science subjects (Sheeja, 2018). NPTEL has solved the problem of accessibility to higher education for the rural population of India. Anyone with an internet connection and zeal to learn can access the gold mine of knowledge that is NPTEL. NPTEL offers about 30-35 courses included in the curriculum of Electrical Engineering with their content based on the syllabus prescribed by All India Council for Technical Education (AICTE) in addition to the syllabus of NPTELaffiliated educational institutions (Bajpai et al., 2015). Disciplines such as Power Electronics, Control and Instrumentation, Power Systems, Power Drives, Energy and other core Electrical Engineering subjects are covered in addition to inter-disciplinary and elective subjects. There are instances of the same discipline being offered by two different institutions which gives students flexibility to choose between two different syllabi. In 2016 Indian Government's MHRD, Department of Space, Doordashan under the Broadcasting Ministry of India's Prasar Bharti coordinated the launch of Direct to Home (DTH) channels which will telecast lectures originating from IITs. If implemented, this project will aid aspiring 
sciendo Порівняльна професійна педагогіка 8(3)/2018

Comparative Professional Pedagogy 8(3)/2018

engineering students, UG students, PG students and industry personnel in an unprecedented manner (Sharma, 2009). Free and Open Source Software in Education (FOSSEE) is a program initiated through National Mission on Education through Information and Communication Technology (ICT) which is responsible for creating free and open source tools for students and researchers. One of such free and open source software created by FOSSEE is eSIM (previously known as Oscad or FreeEDA). eSIM is an electronic design automation tool ordained for students and researchers in the field of Electronic Engineering and Electrical Engineering (Moudgalya, 2014).

Electrical Engineering is one of the main branches of engineering and as it was in the $20^{\text {th }}$ century, Electrical Engineering has its own distinctive impact on the $21^{\text {st }}$ century. However, with the overwhelming growth of software companies and information technology industry in India, it is very common for Electrical Engineering UG graduates to take up jobs in the exponentially growing information technology industry in India. The first olive branch towards the Indian economy was extended by former Finance Minister Dr. Manmohan Singh in 1991 when he presented a budget which liberalized Indian economy. This opened the doors for private enterprises such as Adani Power to foray into the massive power generation and distribution industry of India which in turn created numerous sustainable jobs for electrical engineers throughout India (Murthy, 2004). Students who are in their final year and students who have completed their UG program in Electrical Engineering can apply for a multitude of jobs in numerous Public-Sector Undertakings (PSUs) offering a diverse range of job profiles upon passing Graduate Aptitude Test for Engineering (GATE) under the condition of successfully completing selection procedures for the PSU that they have applied for. Notable PSUs which recruit through GATE are Bharat Heavy Electrical Limited, National Thermal Power Corporation Limited, and Oil and Natural Gas Corporation Limited. Students can also apply for Indian Engineering Services through Engineering Services Examination (ESE) which is considered one of the most onerous exams of India and offers elite job profile for its postgraduate students. Indian Défense Service of Engineers, Indian Railway Service of Electrical Engineers and Indian Naval Armament Service are some reputable organizations which recruit electrical engineers through Engineering Services Examinations. India became committed to bringing down greenhouse gas emissions when it became a signatory to the Paris Climate Agreement. This is the second olive branch extended to the Electrical Engineering community of India. India plans to reduce its reliance on thermal energy by replacing it with clean renewable energy. Jawaharlal Nehru National Solar Mission (JNNSM) is a project dedicated to generating $100 \mathrm{GW}$ of electricity through solar power which will generate numerous sustainable jobs for electrical engineers in India (Saraswat et al., 2018). Electrical engineers of India will also play a leading role in the utilization of India's $7500 \mathrm{~km}$ long coast line which is being capitalized for installation of Wind Energy farms (Chari, 2010). Indian Government's National Action Plan on Climate Change is dependent on electrical engineers for they are considered the ones who can bring success and positive socio-economic change in India.

We have used the latest update of Quacquarelli Symonds (QS) ratings to determine the position of Indian engineering and technology institutions in compression with BRICS countries. China leads the way in terms of offering high quality engineering and technology education as it is apparent in the QS rankings. Institutions from the People's Republic of China occupy the first five positions, namely Tsinghua University, Peking University, Fudan University, University of Science and Technology of China and Shanghai Jiao Tong University 
in the given order. These rankings are an indication of how systematic and productive China's academia-industry relationship is, they also are an ode to China's manufacturing policy. Indian Institute of Science-Bangalore is the sole representative of the world's second most populous nation in the Top-10 positions of these rankings, signaling that even though concrete steps have been taken by the Indian Government to provide quality education to its youth, it will require more efforts to improve its ranking when compared to BRICS nations as well as other nations of the world. Similar to India, Russia and Brazil also have a single representative in the Top-10 educational institutes of BRICS nations in the form of Lomonosov Moscow State University and Universidade de São Paulo respectively. South Africa is represented by University of Cape Town at the 14th position.

\section{CONCLUSIONS}

Having conducted thorough research we came to the conclusion that Indian Government should make it mandatory for institutes and industry to coordinate with each other for the betterment of the country's economy and students' future. A healthy and highly functioning academia-industry relationship will complement the rapidly growing manufacturing industry in India as well as assist "MAKE IN INDIA" to become an astounding success. We also urge Indian Government to provide adequate funding to the world's $4^{\text {th }}$ largest Ph. D holder population so that India can keep up with other countries in terms of research and development innovation.

Electrical Engineering is a core engineering branch which is vital for other engineering branches to flourish and is considered an evergreen branch by aspiring engineers. It is imperative for electrical engineers to use their ability as much as possible to bring positive socio-economic change to the country. Electrical Engineering academia and industry have done a lot to adapt to changing technological and economic scenarios and continue to be the force for good in the society.

India derives most of its electricity needs from fossil fuels. However, with the implementation of Jawaharlal Nehru National Solar Mission launched by India's former Prime Minister Dr Manmohan Singh India is moving towards a future where renewable energy technology will take over thermal energy. The authors of this paper would like to emphasize the role of electrical engineering students in the successful implementation of renewable energy technology in India. Digital India is an ambitious scheme launch by the Government of India which aims to spread digital literacy and smart ways of doing day to day regular activities using digital techniques. One of such components of this program is the implementation of Smart Grids. Electrical Engineers of India have contributed towards research and development of smart grids, Tata Power Delhi Distribution is an organization which is committed to provision of smart grid services and employs electrical engineers. Electrical Engineering Academia should include elements of cybersecurity and data privacy in order to help the upcoming generation of electrical engineers in India to actively contribute towards the development of smart grid technology in India. Indian Institute of TechnologyKharagpur and Indian Institute of Technology-Madras are working in collaboration with IBM for smart grid research in which electrical engineers make a significant contribution. Another challenge for Electrical Engineering Academia arises as a result of the rapid spread of renewable energy technology in the automotive sector. As fossil fuel-based internal combustion engines are being replaced by energy efficient induction motor engines, UG and PG curriculum of Electrical Engineering must be revised to accommodate automotive subjects so that electrical engineers adapt to the electric car industry demand. Electrical 
sciendo Порівняльна професійна педагогіка 8(3)/2018

Comparative Professional Pedagogy 8(3)/2018

Engineering elective subjects in UG and PG programs of Mechanical Engineering should be added, as well as elective subjects concerning automobiles should be introduced in UG and PG programs of Electrical Engineering. All these aspects and ways of their implementation are going to be outlined in our further research.

\section{REFERENCES}

1. AICTE Report. (2018). Retrieved from https://www.facilities.aicte-india.org/ dashboard/pages/dashboardaicte.php.

2. Bell, A. G. (1876). U.S. Patent No. 174,465. Washington, DC: U.S. Patent and Trademark Office.

3. Borisov, V. P. (2016). Technology in Russia: History, Events, Views. Icon, 22, $20-27$.

4. Bajpai, S., \& Khare, S. (2015). Mechatronics Engineering Education in India. Comparative Professional Pedagogy, 5 (4), 73-79.

5. Bajpai, S., Khare, S., \& Yadav, R. (2016). Control Education in India: Present \& Future. IFAC-Papers Online, 49 (1), 813-818.

6. Bajpai, S., \& Kidwai, N. R. (2017). Renewable Energy Education in India. Comparative Professional Pedagogy, 7 (4), 103-113.

7. Canizares, C. A., \& Faur, Z. T. (1997). Advantages and disadvantages of using various computer tools in electrical engineering courses. IEEE Transactions on education, 40 (3), 166-171.

8. Chakraborty, A., Singh, M. P., \& Roy, M. (2018). Green Curriculum Analysis in Technological Education. International Journal of Progressive Education, 14 (1), 122-129.

9. Chari, P. R. (2010). India and Natural Disasters. In Global Warming and Climate Change. London: Palgrave Macmillan.

10. EE department, National Institute of Technology, Tiruchirappalli (2018). Retrieved from https://www.nitt.edu/home/academics/departments/eee/.

11. Holmøy, T., \& Moen, S. M. (2010). Assessing vitamin D in the central nervous system. Acta Neurologica Scandinavica, 122, 88-92.

12. Keithley, J. F. (1999). The story of electrical and magnetic measurements: from 500 BC to the 1940s. John Wiley \& Sons.

13. Khare, S., Bajpai, S., \& Bharati, P. K. (2015). Production engineering education in India. Management and Production Engineering Review, 6 (1), 21-25.

14. Khare, S., Chowdhry, S., \& Bajpai, S. (2014). Control engineering education in India. Power, Control and Embedded Systems (ICPCES). 2014 International Conference on IEEE.

15. Khare, S., Chatterjee, A., Bajpai, S., \& Bharati, P. K. (2016). Manufacturing engineering education in India. Management and Production Engineering Review, 7 (1), $40-44$.

16. Moudgalya, K. M. (2014). Oscad: open-source computer-aided design tool. Linux Journal, 2014 (241), 4.

17. Murthy, N. (2004). The impact of economic reforms on industry in India: a case study of the Software Industry. India's emerging economy, 5, 217-222.

18. Murti, V. G. (1972). Electrical engineering education in India. IEEE Transactions on Education, 15 (4), 214-219. 
sciendo Порівняльна професійна педагогіка 8(3)/2018 Comparative Professional Pedagogy 8(3)/2018

19. Palit, D., \& Bandyopadhyay, K. R. (2017). Rural electricity access in India in retrospect: A critical rumination. Energy Policy, 109, 109-120.

20. Saraswat, J., Agarwal, V., \& Mukherjee, M. (2018). Effectuation of Renewable Energy as an Effective Mitigation Approach towards Climate Change. In Advances in Health and Environment Safety (pp. 21-28). Singapore: Springer.

21. Sarkar, S. (2015). Domesticating electric power: Growth of industry, utilities and research in colonial Calcutta. The Indian Economic \& Social History Review, 52 (3), 357-389.

22. Sarkar, S. (2017). The Electrification of Colonial Calcutta: Role of the Innovators, Bureaucrats and Foreign Business Organization, 1880-1940. Studies in History, 34, 48-76.

23. Sheeja, N. (2018). Open Educational Resources in India: A Study of NPTEL and its Usage. Library Herald, 56 (1), 122-129.

24. Singh, S., Saurabh, K., \& Bajpai, S. (2016). History of Electric Power in India (1890-2015). Journal of Electrical and Power System Engineering, 2 (1), 241-256.

25. Seely, B. E. (1999). The Other Reengineering of Engineering Education, 1900-1965. Journal of Engineering Education, 88 (3), 285-294.

26. Thue, W. A. (2016). Electrical power cable engineering. CRC Press.

27. Terman, F. E. (1976). A brief history of electrical engineering education. Proceedings of the IEEE, 64 (9), 1399-1407. 